\title{
Chemical and functional properties of glycomacropeptide (GMP) and its role in the detection of cheese whey adulteration in milk: a review
}

\author{
Neelima • Rajan Sharma • \\ Yudhishthir Singh Rajput • Bimlesh Mann
}

Received: 26 April 2012 / Revised: 31 October 2012 / Accepted: 5 November 2012 /

Published online: 24 January 2013

(C) The Author(s) 2013. This article is published with open access at Springerlink.com

\begin{abstract}
Glycomacropeptide (GMP) is a C-terminal part (f 106-169) of kappacasein which is released in whey during cheese making by the action of chymosin. GMP being a biologically active component has gained much attention in the past decade. It also has unique chemical and functional properties. Many of the biological properties have been ascribed to the carbohydrate moieties attached to the peptide. The unique set of amino acids in GMP makes it a sought-after ingredient with nutraceutical properties. Besides its biological activity, GMP has several interesting techno-functional properties such as wide $\mathrm{pH}$ range solubility, emulsifying properties as well as foaming abilities which are shown to be promising for applications in food and nutrition industry. These properties of GMP have given new dimension for the profitable utilization of cheese whey to the dairy industry. A number of protocols for isolation of GMP from cheese whey have been reported. Moreover, its role in detection of sweet/rennet whey adulteration in milk and milk products has also attracted attention of various researchers, and many GMP-specific analytical methods have been proposed. This review discusses the chemico-functional properties of GMP and its role in the detection methods for checking cheese or sweet whey adulteration in milk. Recent concepts used in the isolation of GMP from cheese whey have also been discussed.
\end{abstract}

Neelima $\cdot$ R. Sharma $(\varangle) \cdot$ B. Mann

Dairy Chemistry Division, National Dairy Research Institute, Karnal 132001, India

e-mail: rajansharma21@gmail.com

\section{Y. S. Rajput}

Division of Animal Biochemistry, National Dairy Research Institute, Karnal 132001, India 
糖巨肽的化学和功能特性以及在检测干酷制作过程中掺假乳清的作用: 综述

摘要：糖巨肽 (GMP) 是由 $\mathrm{K}$-酪蛋白的 C-末端部分 (f106-69) 构成的一种多肽, 是在凝 乳酶的作用下从干酪制作过程中的乳清中释放出来。过去十年来, 糖巨肽作为一种生物活 性成分, 引起了人们广泛的关注。它有其独特的化学和功能特性。GMP 的大多数生物特性 应归因于与肽连接的糖基。GMP 中独特的氨基酸组成使它作为保健食品很受欢迎。GMP 除 了具有生物活性外, 它还具有使人们感兴趣的加工特性, 如较广 $\mathrm{pH}$ 范围的溶解性、乳化性 和起泡性, 这些特性使GMP在食品和营养方面有较广阔的应用前景。GMP 的这些特性给人们 一种全新的思维, 那就是将干酪乳清合理的运用于乳制品工业中。很多关于从干酪乳清中 分离GMP的实验方案和计划被报道。然而, GMP 在检测奶中甜乳清/凝乳乳清掺假方面的作 用也引起了很多研究工作者的广泛关注, 提出了很多分析 GMP 的具体方法。本综述讨论了 GMP 的化学和功能特性以及在干酪和甜乳清掺假中的作用, 探讨了近期从干酪乳清中分离 GMP 的新的想法。

Keywords Glycomacropeptide - Chemico-functional properties · Cheese whey · Adulteration

关键词 糖巨肽·化学 - 功能特性·干酪乳清・掺假

\section{Introduction}

In the middle of the twentieth century, scientists first found evidence about the presence of protein bound sialic acid in milk (György et al. 1954) while working on a variant of Lactobacillus bifidus. They observed that human and cow milk contain some bifido-factor which is not destroyed or altered in its activity even by autoclaving, although the ash was found to be inactive. However, it was the pioneering work of French workers (Delfour et al. 1965) who for the first time established that milk contains a sialic acid bound protein called kappa-casein $(\mathrm{K}-\mathrm{CN})$. They also reported that glycomacropeptide (GMP), a sialic acid rich peptide, is formed by the cleavage of $\mathrm{K}-\mathrm{CN}$ between $\mathrm{Phe}_{105}-\mathrm{Met}_{106}$ by the action of rennet (chymosin) during the manufacture of cheese. It took many more years when GMP was taken as a new product opportunity. The GMP preparations until then were not pure enough to replace synthetic amino acid mixtures in the management of phenylketonuria and severe liver disease (Marshall 1991). Although GMP is released from $\mathrm{k}-\mathrm{CN}$ during cheese making by the action of rennet, smaller concentrations of GMP also exist in bovine milk. However, GMP released from casein is almost ten times higher than free GMP in mature milk (Furlanetti and Prata 2003). GMP constitutes 20-25\% of total proteins in whey products viz., whey powder, whey protein isolates (WPI), whey protein concentrates (WPC) etc., manufactured from cheese whey (Farías et al. 2010). It is recognized as a bioactive peptide and is thought to be an ingredient with a potential use in functional foods, and thus great interest has been generated for its isolation. The composition of GMP is variable and depends on the particular whey source and the fractionation technology employed in its isolation (Martín-Diana et al. 2006). Earlier, attempts were mainly made to review the isolation and biological 


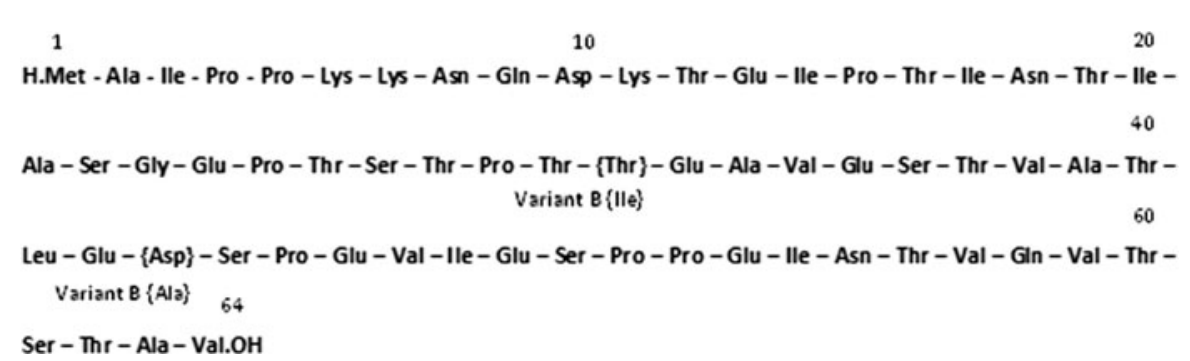

Fig. 1 Primary structure of bovine GMP variant A. The enclosed amino acids represent the sites corresponding to B variant (Eigel et al. 1984)

properties of GMP (Brody 2000; El-Salam et al. 1996; Thomä-Worringer et al. 2006). This article aims to discuss the chemical and functional properties of GMP and its role in the detection methods for checking cheese whey adulteration in milk and milk products. Some of the recent concepts used for the isolation of GMP from cheese whey are also discussed.

\section{Chemical properties of GMP}

GMP is significantly rich in the amino acids Pro, Glu, Ser, and Thr but depleted in Trp, Tyr, Phe, and Cys (Fig. 1). Of the three branched chain amino acids viz., Leu, Ile, and Val, GMP is rich in Ile and Val. The true 3D structure of GMP could not be established as crystallization has not been possible and a theoretical model has been suggested (Kreuß et al. 2009b). It has been predicted that GMP is a random coil or intrinsically disordered peptide without a defined secondary or tertiary structure and there is change in the conformation with change of ionic strength, $\mathrm{pH}$, and presence of other molecules. These authors have predicted the 3D structure of GMP through protein modeling and have shown that a large part of the peptide has a strong negative charge, while there are three small positively charged domains at the $\mathrm{N}$ terminus. They also reported that at $\mathrm{pH} \mathrm{7.0,} \mathrm{the} \mathrm{grand} \mathrm{average} \mathrm{of} \mathrm{hydropathicity} \mathrm{has} \mathrm{a} \mathrm{value} \mathrm{of}$ -0.322 , characterizing the peptide as more hydrophilic than hydrophobic. This value should be significantly decreased (more hydrophilic) in the case of glycosylated GMP due to the sialic acid residues.

\subsection{Glycosylation}

The carbohydrates are attached to $\mathrm{K}-\mathrm{CN}$ at $\mathrm{Thr}_{131}, 133,135,142$ and $\mathrm{Ser}_{141}$ positions through $O$-glycosylation linkages (Eigel et al. 1984). These positions are located more or less in the middle of the peptide backbone. The heterogeneous carbohydrate chains are the unique characteristics of GMP, not found in the remaining part (1 to 105 ) of $\mathrm{k}-\mathrm{CN}$. Each of the GMP fractions with different carbohydrate chains might be responsible for different biological functions ( $\mathrm{Li}$ and Mine 2004). The distribution of monosaccharide, disaccharide, trisaccharide (straight and branched), and tetrasaccharide chains is $0.8 \%, 6.3 \%, 18.4 \%, 18.5 \%$, and $56.0 \%$, respectively, as determined by HPLC (Saito et al. 1991). Mollé and Léonil (1995) using electrospray-ionization mass spectrometry (ESI-MS) found that out of five potential glycosylation sites, a 
maximum of three are substituted with highly glycosylated carbohydrate chains which may contain up to six $N$-acetyl neuraminic acid (NeuNAc) residues per molecule. GMP is particularly rich in sialic acids which are substituted neuraminic acid derivatives, and the main representative forms of sialic acid are NeuNAc and N-glycolylneuraminic acid (Salcedo et al. 2011). The majority of the carbohydrate chains contain NeuNAc as a terminal residue $\alpha 2-3$ or $\alpha 2-6$ linked to GalNAc or Gal, respectively (Cherkaoui et al. 1997). Commercially available GMP with $78-83.7 \%$ protein content contains $7-9 \%$ of sialic acid (Arla Food Ingredients and Davisco Foods International, Inc.). Sialic acid offers one route of determining GMP concentration in a protein mixture. This is achieved by its reaction with certain compound leading to the formation of chromophore/fluorescent derivative which can be quantified (Neelima et al. 2012). On the basis of glycosylation, GMP can be classified into two major fractions: the glycosylated and phosphorylated glyco-peptide (gGMP), and the non-glycosylated but phosphorylated aglyco-peptide (aGMP) (Kreuß et al. 2009b). Fourteen glycosylated forms of GMP have been identified (Mollé and Léonil 1995) and gGMP form of GMP represent about 50\% of the total GMP (Mollé and Léonil 2005). Heating of the milk or whey prior to isolation of GMP has an influence on the extent of glycosylation in isolated GMP; more severe heating produces GMP with less glycosylation (Taylor and Woonton 2009). Many of the biological and functional properties of GMP have been attributed to sialic acids (Fernando and Woonton 2010), but others have been linked to peptide part and still others are due to both peptide as well as glycan part (Table 1). Due to heterogeneity of GMP (because of glycosylation), GMP does not separate as a single peak in RP-HPLC, and this creates a problem in interpretation of cheese whey detection methods which are based on HPLC.

Table 1 Role of carbohydrate moiety and peptide backbone in various biological properties of GMP

\begin{tabular}{|c|c|c|c|}
\hline Biological properties & $\begin{array}{l}\text { Role of } \\
\text { carbohydrate } \\
\text { moiety }\end{array}$ & $\begin{array}{l}\text { Role of peptide } \\
\text { backbone }\end{array}$ & References \\
\hline Reduction of gastric secretion & & $\checkmark$ & Aleinik et al. (1984) \\
\hline Bifido-factor & & $\checkmark$ & Azuma et al. (1984) \\
\hline Anti-cariogenic effect & & $\checkmark$ & $\begin{array}{l}\text { Neeser et al. (1988, 1994); } \\
\text { Aimutis (2004) }\end{array}$ \\
\hline Inhibition of cholera toxin & $\checkmark$ & & Kawasaki et al. (1992) \\
\hline Modulation of immune response & $\checkmark$ & $\checkmark$ & $\begin{array}{l}\text { Otani et al. (1992); } \\
\text { Requena et al. (2010) }\end{array}$ \\
\hline Hemagglutination inhibition & $\checkmark$ & & Kawasaki et al. (1993a) \\
\hline Stimulation of cholecystokinin release & $\checkmark$ & $\checkmark$ & $\begin{array}{l}\text { Beucher et al. (1994); } \\
\text { Burton-Freeman (2008) }\end{array}$ \\
\hline Prevention of intestinal infection & $\checkmark$ & & Nakajima et al. (2005) \\
\hline Nutritional management of phenylketonuria & & $\checkmark$ & $\begin{array}{l}\text { LaClair et al. (2009); van } \\
\text { Calcar and Ney (2012) }\end{array}$ \\
\hline $\begin{array}{l}\text { Antibacterial and probacterial activity } \\
\text { of pepsin-treated GMP }\end{array}$ & & $\checkmark$ & Robitaille et al. (2012) \\
\hline
\end{tabular}




\subsection{Isoelectric point $(\mathrm{p} I)$}

GMP is an acidic peptide with $\mathrm{p} I$ of around 4, highly soluble and heat stable (Thomä et al. 2006). This relatively acidic $\mathrm{p} I$ is related to the high amount of acidic amino acid side chains (Glu and Asp). GMP does not have a single $\mathrm{p} I$ because of heterogeneity in glycosylation and phosphorylation (Cherkaoui et al. 1997; Kreuß et al. 2008; Lieske et al. 2004; Nakano and Ozimek 2002; Silva-Hernandez et al. 2002). Using anion exchange chromatography, it was suggested that all sialylated GMP had an apparent $\mathrm{p} I<3.8$ (Nakano and Ozimek 2000b). The $\mathrm{p} I$ of 64 amino acids is around 4, but the sialate and phosphate have relatively low $\mathrm{p} K_{\mathrm{a}}$ values of 2.6 and 2.0 , respectively. The $\mathrm{p} I$ of GMP depends upon sialic acid and phosphate content present in it. Using laser Doppler electrophoresis and zeta potential measurement data, the $\mathrm{p} I$ of gGMP and aGMP was found to be 3.15 and 4.15, respectively (Kreuß et al. 2009b). GMP contains two Asp, seven or eight Glu (depending on genetic variants), one phosphorylated Ser, and three Lys residues. Below the $\mathrm{p} I$, GMP molecules lose the negative charge of the Glu and Asp residues, carboxyl group at the $\mathrm{C}$ terminus, and the sialic acid residues. The positive charge of GMP below its $\mathrm{p} I$ is because of the Lys residue and the positively charged $\mathrm{N}$ terminus, while all Glu and Asp residues are protonated (Farías et al. 2010; Kreuß et al. 2009b). The variation in the $\mathrm{p} I$ of GMP among aGMP and gGMP leads to multiple peaks which may affect the interpretation of the result in capillary electrophoresis (CE)-based cheese whey detection methods. Difference in $\mathrm{p} I$ of gGMP and aGMP has been exploited for the selective isolation of gGMP from commercial GMP preparations (Kreuß and Kulozik 2009).

\subsection{Molecular weight}

Using liquid chromatographic ESI-MS, the aGMP form of GMP was observed to have a molecular mass between 6,755 and 6,787 Da depending on the genetic variant of $\mathrm{k}-\mathrm{CN}$ from which it was derived. The average molecular mass of total gGMP is about 7,500 Da with the highest mass of up to 9,631 corresponding to highly glycosylated form (Mollé and Léonil 1995, 2005). It has also been suggested that the mass ratio between aGMP and the state of maximum glycosylation of gGMP differs from 7,000 Da to 11,000 Da with $36.4 \%$ overall molecular mass contribution of glycans (Kreuß et al. 2009b). In literature, often the molecular weight of GMP is given two to three times greater than the theoretical one which is caused by the association of monomers to form aggregates. The behavior of GMP on SDS-PAGE indicates that peptide is in polymeric form with molecular weight ranging from 14 to $30 \mathrm{kDa}$ (Farías et al. 2010; Galindo-Amaya et al. 2006). It has been suggested that GMP has the ability of associating and dissociating under selected $\mathrm{pH}$ conditions. Earlier, it was proposed that the 9-kDa monomer of GMP is obtained at $\mathrm{pH} \leq 4$ and the polymer of 45-50-kDa GMP is obtained at pH higher than 4 (Kawasaki et al. 1993b). On the contrary, Nakano and Ozimek (1998) used gel chromatography over Sephacryl S-200 gel and suggested that GMP is an aggregate of three monomers, and the molecular weight was not affected by changes in $\mathrm{pH}$.

It has also been suggested that $\mathrm{pH}$-dependent interactions between GMP molecules seem to take place within the $\mathrm{K}-\mathrm{CN}$ micelles which influence the resulting GMP product arising from enzymatic cleavage. GMP units in $\mathrm{k}-\mathrm{CN}$ appear to associate 
reversibly depending on $\mathrm{pH}$, whereas the GMP monomers do not tend to associate once they have been formed. The apparent aggregation of GMP is not solely influenced by the actual $\mathrm{pH}$ and strong hydrophobic contacts have been hypothesized which hold together polymeric forms. The tetrameric form of GMP is more hydrophobic than the dimeric and monomeric forms (Mikkelsen et al. 2005). Using dynamic light scattering technique, recent studies indicate that $\mathrm{pH}$ is very important in controlling GMP aggregation. GMP undergoes a pH-dependent self-assembly at room temperature. At $\mathrm{pH}$ below 4.5, GMP self-aggregates due to hydrophobic interactions ultimately leading to gelation. The size of aggregate and gelation further increases on decreasing the $\mathrm{pH}$ and in this role of sialic acid which retains a negative charge at pH 2.2 is important. It has been concluded that self-assembled structures formed at room temperature are partially $\mathrm{pH}$-reversible, but hydrophobically formed dimers appear to be resistant to $\mathrm{pH}$ changes once formed (Farías et al. 2010; Martinez et al. 2012). Self-aggregation of GMP can create problem in its identification and its use as a marker peptide in cheese whey adulteration detection methods which are based on electrophoresis and Western blot. Self-aggregation of GMP may be of interest to protein chemists as the phenomenon is not still fully understood. The separation of individual GMP monomer and its visualization on SDS-PAGE has not yet been achieved. More research efforts are required to delineate the conditions under which GMP exists in monomeric form. This would also pave the way for the development of a simple method for detection of cheese whey adulteration in milk as presence of a 7-kDa (monomeric form of GMP) band in electrophoretic separation of whey obtained after precipitation of casein at 4.6 would ascertain the presence of GMP in suspected milk sample.

\subsection{UV characteristics}

GMP lacks aromatic amino acids (Phe, Trp, and Tyr) and, therefore, it has no absorption at $280 \mathrm{~nm}$. It is known that GMP is only detected in the range of 205$226 \mathrm{~nm}$, and differences in the absorption at 210 and $280 \mathrm{~nm}$ are frequently used to characterize GMP (Oliva et al. 2002); this has been the most commonly used tool to perceive the presence of GMP during HPLC.

\section{Isolation of GMP}

Developments in the knowledge about GMP during the last four decades, comprising its isolation techniques, biological properties, and functional properties used/discovered by different researchers, are compiled in Table 2. Isolation of GMP from cheese whey has been attempted by various techniques such as trichloroacetic acid (TCA) precipitation (Lieske and Konrad 1996), ethyl alcohol precipitation (Saito et al. 1991), ultrafiltration (UF) (Kawasaki et al. 1993b), and chromatographic techniques such as gel chromatography (Nakano and Ozimek 2000a), affinity chromatography (AC) (Saito et al. 1991), hydrophobic interaction chromatography (HIC) (SilvaHernandez et al. 2002), and ion exchange chromatography (IEC) (Tanimoto et al. 1992). Most of the time, it is the combination of different techniques which work best, and these various combinations used for GMP isolation have been categorized 
Table 2 Chronological order of isolation, biological properties, and functional properties used by various workers for GMP

\begin{tabular}{|c|c|c|c|}
\hline Year & Isolation techniques & Biological properties & Functional properties \\
\hline 1970-1980 & $\begin{array}{l}\text { - IEC (Burton and } \\
\text { Skudder 1987) }\end{array}$ & $\begin{array}{l}\text { - Bifido-factor (György } \\
\text { et al. 1954)- Inhibition } \\
\text { of gastric secretion } \\
\text { (Vasilevskaya et al. } \\
\text { 1977) }\end{array}$ & $\begin{array}{l}\text { - Gelation (Burton } \\
\text { and Skudder 1987) }\end{array}$ \\
\hline 1980-1990 & $\begin{array}{l}\text { - Gel filtration, IEC, } \\
\text { and AC (Morr and } \\
\text { Seo 1988) }\end{array}$ & $\begin{array}{l}\text { - Anti-cariogenic (Neeser } \\
\text { et al. 1988)- Modulation } \\
\text { of immune system (Otani } \\
\text { and Monnai 1993; Otani } \\
\text { et al. 1992) }\end{array}$ & $\begin{array}{l}\text { - Emulsification } \\
\text { (Chobert et al. 1989) }\end{array}$ \\
\hline 1990-2000 & $\begin{array}{l}\text { - Alcohol precipitation and } \\
\text { AC (Saito et al. 1991)- } \\
\text { UF (Kawasaki et al. 1993b)- } \\
\text { TCA precipitation (Lieske } \\
\text { and Konrad 1996)- IEC } \\
\text { (Tanimoto et al. 1992)- } \\
\text { Gel chromatography } \\
\text { (Nakano and Ozimek } \\
\text { 2000a) }\end{array}$ & $\begin{array}{l}\text { - Inhibition of cholera } \\
\text { toxin binding (Kawasaki } \\
\text { et al. 1992) }\end{array}$ & $\begin{array}{l}\text { - Overrun } \\
\quad \text { (Marshall 1991) }\end{array}$ \\
\hline 2000-2010 & $\begin{array}{l}\text { - HIC (Silva-Hernandez } \\
\text { et al. 2002)- Enzyme } \\
\text { cross-linking (Tolkach } \\
\text { and Kulozik 2005)- } \\
\text { MAC (Kreuß and Kulozik } \\
\text { 2009)- ATPS (da Silva } \\
\text { et al. 2009) }\end{array}$ & $\begin{array}{l}\text { - Prevention of } \\
\text { intestinal infection } \\
\text { (Nakajima et al. 2005)- } \\
\text { Nutritional management } \\
\text { of phenylketonuria } \\
\text { (LaClair et al. 2009) }\end{array}$ & $\begin{array}{l}\text { - Interfacial behavior } \\
\text { studies (Kreuß et al. } \\
\text { 2009b)-Emulsification } \\
\text { (Martin-Diana et al. } \\
\text { 2005)- Gelation } \\
\text { (Farías et al. 2010) }\end{array}$ \\
\hline 2010 onwards & - UF (Robitaille et al. 2012) & $\begin{array}{l}\text { - Antibacterial and } \\
\text { probacterial activity } \\
\text { of pepsin-treated GMP } \\
\text { (Robitaille et al. 2012) }\end{array}$ & $\begin{array}{l}\text { - Foaming properties } \\
\text { of GMP- } \beta \text {-lg mixed } \\
\text { systems (Martinez } \\
\text { et al. } 2012)\end{array}$ \\
\hline
\end{tabular}

IEC ion exchange chromatography, $A C$ affinity chromatography, $U F$ ultrafiltration, $T C A$ trichloroacetic acid, $H I C$ hydrophobic interaction chromatography, ATPS aqueous two-phase systems, $M A C$ membrane adsorption chromatography

(Tullio et al. 2007) into three different approaches: (a) selective precipitation using heating/alcohol/acetic acid/TCA, (b) membrane filtration using UF/microfiltration $(\mathrm{MF}) /$ dialysis/reverse osmosis/electrodialysis, and (c) selective adsorption using IEC/HIC/AC.

In a comparative study ( $\mathrm{Li}$ and Mine 2004) based on the chromatographic profile of GMP isolated by three methods (TCA fractionation, ethanol precipitation, and UF) from WPI, UF was found to be the most effective in recovering GMP. The method is based on the concept given earlier by Kawasaki et al. (1993b) that at pH 3.5 GMP permeates through UF membranes with a molecular weight cut-off (MWCO) ranging from 20 to $50 \mathrm{kDa}$ and majority of whey proteins such as $\beta$-lactoglobulin, $\alpha$ lactalbumin, immunoglobulins, and bovine serum albumin being held back. The $\mathrm{pH}$ of permeate is then adjusted to 7.0 where GMP forms non-covalent linked polymers and is then concentrated using the same membrane. The recovery rate of GMP using 
this particular technique was around $34 \%$ with more than $80 \%$ GMP in the glycosylated form. The authors recommended a combination of UF and anion exchange chromatography as a suitable and practical approach on an industrial scale. The less recovery obtained by these workers makes the method unsuitable for commercial purpose. The formation of self-assembled aggregates of GMP at low $\mathrm{pH}$ has been reported in some of the recent studies (Martinez et al. 2009; Farías et al. 2010), and it is possible that during UF most of GMP remains with the retentate at $\mathrm{pH} 3.5$ as GMP is already in aggregated or dimer form.

Using an altogether different approach, Tolkach and Kulozik (2005) isolated GMP by enzymatic cross-linking technique. This approach involves pre-treatment of WPC with the enzyme transglutaminase (Tgase). GMP can be cross-linked by Tgase due to the presence of two glutamic acid and three lysine residues in its primary structure. Further, it has been stressed that the presence of sugar residues in GMP provides its hydrophilic character which facilitates the enzyme action. On the other hand, native whey proteins show much less sensitivity to be cross-linked by the Tgase due to their globular structure with relatively little exposure of the protein chain to the exterior. The GMP aggregates are then removed by MF or diafiltration (DF). However, the procedure only separates native whey proteins from GMP and may not be applicable to heated whey. As cross-linking of other milk proteins by Tgase changes its functional properties (Bönisch et al. 2007; Czernicka et al. 2009), it is expected that functional properties of GMP isolated by Tgase would also change. Further investigation in this regards is required.

The $\mathrm{p} I$ of GMP is around 4.0 while $\mathrm{p} I$ of other major whey proteins is above 4.8 (Fox and McSweeney 1998). This difference in $\mathrm{p} I$ has been used in the pilot-scale isolation of GMP using anion-exchange membrane adsorption chromatography (MAC) (Kreuß and Kulozik 2009). The chemistry and binding conditions were given earlier by the same group (Kreuß et al. 2008), who developed and optimized a process for separation of glycosylated and non-glycosylated fractions of the macropeptide using MAC. The module consisted of a spiral packed cellulose-based strong anionic membrane coiled around a solid core. The fouling was decreased by prior MF of whey or by increasing the temperature of the adsorption process. The process development further included a desalting and concentration step, which was performed by a $10-\mathrm{kDa}$ MWCO UF/DF. The efficiency of the UF was strongly influenced by the $\mathrm{pH}$ of the solutions and showed best performance at $\mathrm{pH} 4.1$ for the eluate. Using this technique, 91\% purity of GMP (glycosylated form) could be achieved. Fouling of the membrane was found to be a major issue in this isolation procedure. This approach allows selective isolation of glycosylated form of GMP from commercial GMP preparation and may appeal to manufacturers of GMP for its further fractionation and product diversification.

The aqueous two-phase systems (ATPS) have been widely used in biochemistry, cell biology, and biotechnology (Oliveira et al. 2002). An ATPS is formed when two water-soluble polymers, such as polyethylene glycol (PEG) and dextran, or a polymer and a salt are dissolved in water beyond a critical concentration at which two immiscible phases are formed. Partitioning of GMP using ATPS has been attempted by da Silva et al. (2009). In their study, the use of PEG and sodium citrate as ATPS for the partitioning of GMP has been proposed. The parameters (PEG molar mass, tie line length, $\mathrm{pH}, \mathrm{NaCl}$ concentration, and temperature), which affect the partitioning 
behavior of the protein, were also investigated. It was verified that larger tie line lengths and higher temperatures favor GMP partition to the PEG phase. Furthermore, PEG molar mass and concentration had a slight effect on GMP partition. The increase in the molar mass of PEG induced a reduction of the protein solubility in the top PEG-rich phase. A protein recovery higher than $85 \%$ was obtained in the top phase (PEG-rich phase) of these systems, demonstrating its suitability as a starting point for the isolation of GMP. Later, PEG/ammonium sulfate ATPS was also used to separate GMP (Wu et al. 2012). It was found that the molecular weight of PEG and concentration of both the phases influence the partitioning of GMP. These experiments showed that $18 \%(\mathrm{w} / \mathrm{w})$ PEG6000 and $15 \%(\mathrm{w} / \mathrm{w})$ ammonium sulfate were the optimum system in which the protein recovery was around $70 \%$. The removal of polymers from isolated GMP requires another step of chromatography like sizeexclusion chromatography which makes the isolation procedure tedious.

All the aforementioned novel approaches for the isolation of GMP from cheese whey are in their preliminary stages. The earlier literature indicates that combination of ion-exchange chromatography and UF provides the best result in terms of recovery as well as for scale-up operations. The manufacturer of GMP would be interested in those approaches which allow the use of the spent whey for other food applications. Since the $\mathrm{p} I$ of GMP varies with extent of glycosylation, more research may be required to elaborate the optimum conditions of $\mathrm{pH}$, type of exchanger, elution buffer, temperature conditions, etc. to recover maximum GMP from cheese whey.

\section{Functional properties of GMP}

The functional properties of GMP which have received attention include its emulsification, foaming, and gel formation ability. Like the biological properties, functional properties are equally affected by the glycosylation of GMP. It is worth mentioning here that the solubility of GMP in aqueous medium is proportional to its glycolsylation (Taylor and Woonton 2009).

\subsection{Emulsification and foaming properties}

Emulsifying and foaming properties are among the most important functional properties of milk proteins, and the characteristics of most dairy products depend on how the milk protein fraction is organized at fat-serum and air-serum interfaces (Dickinson 2003). GMP present in WPC also contributes to the emulsification (Chobert et al. 1989). When compared with WPC, the emulsifying activity index of GMP was shown to be significantly lower $\left(36 \mathrm{~m}^{2} \mathrm{~g}^{-1}\right.$ for GMP and $185 \mathrm{~m}^{2} \mathrm{~g}^{-1}$ for WPC), but GMP had more stable emulsifying activity index with respect to $\mathrm{pH}$ than WPC, suggesting the possible utilization of GMP as emulsifier in foods which undergo large $\mathrm{pH}$ variations during processing, i.e., fermented dairy products (Martin-Diana et al. 2005). The glycosylated and non-glycosylated GMP fractions exhibit different emulsification properties as glycan moiety significantly affect the surface activity (Fig. 2a). In a study by Kreuß et al. (2009b), aGMP showed a higher emulsifying activity index of $150.7 \mathrm{~m}^{2} \mathrm{~g}^{-1}$ while gGMP achieved a lower value of $98.5 \mathrm{~m}^{2} \mathrm{~g}^{-1}$. Also, the stability of emulsions was 1.4 times higher for aGMP as compared to gGMP. The $\mathrm{pH}$ of the emulsion greatly 


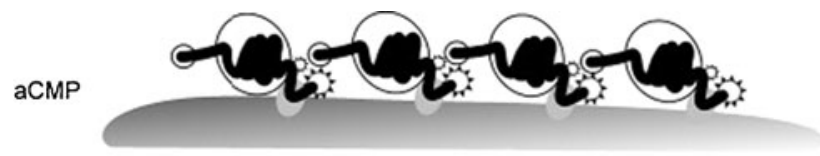

(a)

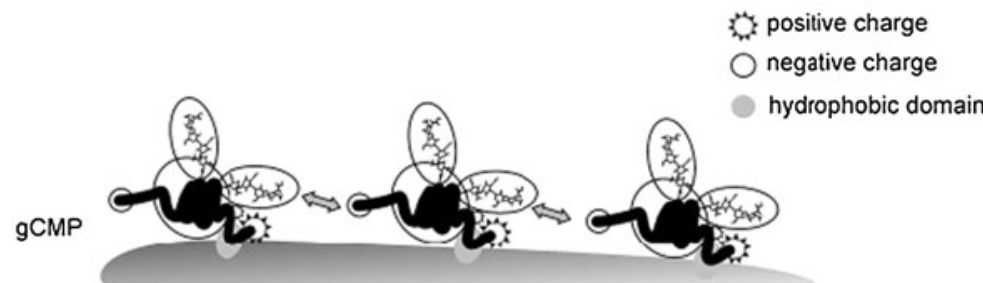

(b)

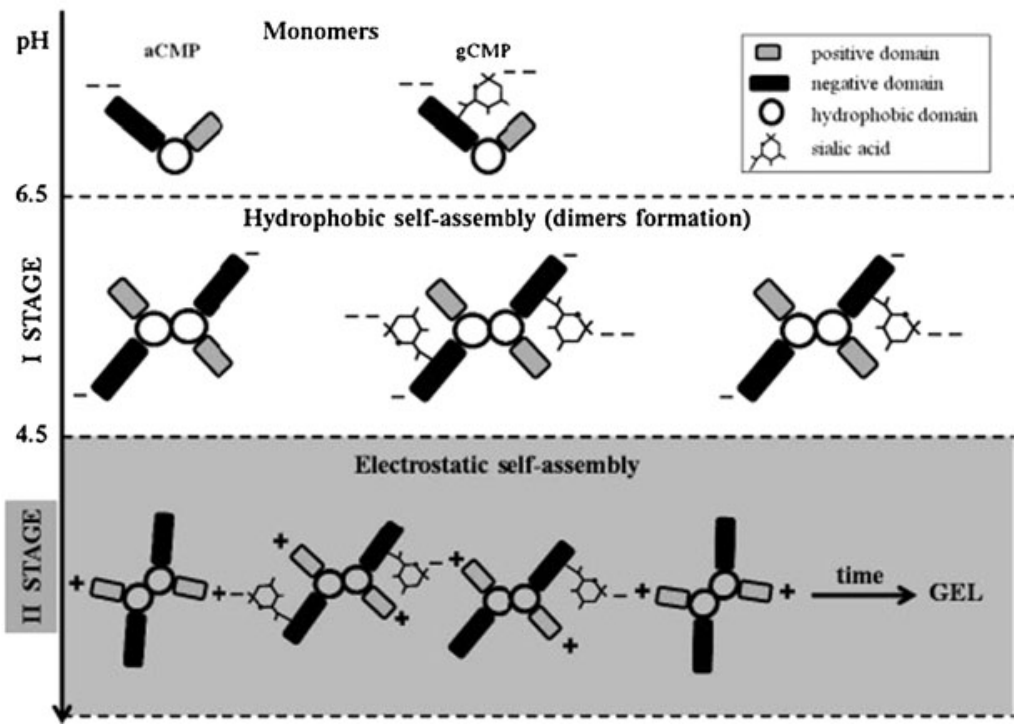

Fig. 2 Role of glycosylation on GMP self-assembly and foaming property a adsorption of aGMP and gGMP at hydrophobic/hydrophilic interface. aGMP can make a stable layer at the interface while in gGMP glycan chains create repulsive forces; $\mathbf{b}$ a model to explain the $\mathrm{pH}$-dependent self-assembly of GMP. Below $\mathrm{pH}$ 4.5, glycan chains provide a negative charge for gel formation. Adapted from Kreuß et al. (2009b) and Farías et al. (2010). (Figures used with permission)

influences both the formation and stability of the emulsions formed by GMP. At the oilwater interface, above the $\mathrm{p} I$ there is an average stabilized adsorption of peptide with negative repulsion between individual oil droplets. At the $\mathrm{p} I$, due to lack of repulsive forces, the oil droplets coalesce. Below the $\mathrm{p} I$, there is repulsive positive charge which stabilizes the oil droplets.

The hydrophilic nature of GMP reduces the emulsifying activity as compared to native amphipathic $\mathrm{k}-\mathrm{CN}$. Attempts have been made to modify the emulsification activity of GMP by conjugating it with other molecules such as lactose (Moreno et al. 2002) and fatty acids (Wong et al. 2006). Lactose has been conjugated with GMP using Maillard reaction chemistry and such conjugation has been reported to increase the emulsifying activity without significantly reducing the macropeptide solubility (Moreno et al. 2002). Long-chain fatty acids have been conjugated to GMP 
using lipophilization reaction involving $N$-hydroxysuccinimide fatty esters (Wong et al. 2006). The modified GMP has been shown to have improved functionality as a surfactant with enhanced antibacterial activity towards gramnegative bacteria.

Like emulsification, foaming ability also depends upon glycosylation. GMP is a good foam-building peptide as it efficiently reduces surface tension and assures high gas content during foaming but makes unstable foams compared to foams made with WPI (Thomä-Worringer et al. 2007). Moreover, 10\% of whole GMP solution was found to give a higher overrun, but inferior foam stability compared with egg white (Marshall 1991). Kreuß et al. (2009a) studied both gGMP and aGMP for their foaming properties in terms of overrun, foam rigidity, and drainage at $\mathrm{pH}$ 6.0. They found that aGMP-stabilized foams show significantly higher foam rigidity and stability than foams stabilized with gGMP, whereas both fractions yield a high foaming ability with overruns of around $600 \%$. They hypothesized that a combination of steric and electrostatic repulsion of the glycan is responsible for this difference.

\subsection{Gel formation}

Gel is an intermediary form between solid and liquid. Food processing and the development of new products require ingredients such as the gelling agents, which build up a structural matrix that supplies food its desirable texture. It has been proposed that GMP has the capability to form gel and this is because of strong hydrophobic links between the monomer molecules. At neutral $\mathrm{pH}$, most of the hydrophobic domains (containing Val, Pro, Ile, Ala, and Met) cannot interact as these are masked by strong charge density of negatively charged amino acids (Glu and Asp). Above $\mathrm{pH}$ 6.5, Glu and Asp get deprotonated which produces a strong negative shield thereby preventing GMP self-association. Below $\mathrm{pH} \mathrm{6.5,} \mathrm{the} \mathrm{protonation} \mathrm{of}$ these acidic amino acids increases which decreases their shielding effect, allowing the hydrophobic domains to interact causing self-assembly. GMP solutions (3-10\%, w/ w) below $\mathrm{pH} 4.5$ show time-dependent self-assembly at room temperature leading to gelation. A GMP self-assembly model (Fig. 2b) has been proposed according to which self-assembly occurs in two different stages - a first stage of hydrophobic interaction to form dimers and in the second stage the dimers further interact through electrostatic bonds to form gels. In the second stage, the presence of charged glycosidic side chain plays an important role as it contributes to the negative charge at low pH (Farías et al. 2010).

The effect of added WPC and GMP on the rheological and structural properties of fermented milk prepared from goat milk has been studied. The addition was found to enhance elasticity versus viscosity of the gel, thereby favoring the use of GMP in fermented milks leading to the formation of a more orderly and structured gel compared to using WPC (Martin-Diana et al. 2004).

\section{Role of GMP in detection of cheese whey adulteration in milk}

Adulteration of milk continues to represent a major concern not only for consumers but for manufacturers also, as it affects the quality of dairy products. Adulteration of 
milk by adding cheese whey is economically attractive because cheese whey cost is four to five times lower than milk and it does not adversely affect the sensory perception of product. Furthermore, because of its high biological oxygen demand, disposal of cheese/rennet whey is a problem, and is often used for adulteration of milk and milk products (Chávez et al. 2008; Martín-Hernández et al. 2009).Various methods for detection of cheese whey in milk have been reported. The developed methods can broadly be categorized into two different groups. One group consists of methods based on the compositional difference between cheese/rennet whey and milk (non-GMP-based methods). These include the determination of the ratio of casein and whey protein using derivative spectroscopy (Miralles et al. 2000), electrophoretic analysis (De Souza et al. 2000), by analyzing casein bound phosphorus index (Wolfschoon-Pombo and Furtado 1989) and the quantification of cysteine and cystine ratio through polarography (Mrowetz and Klostermeyer 1976). The other group includes methods which are mainly based on the presence of GMP in the suspected samples and are known as GMP-based methods. Although free GMP is also present in mature milk, as mentioned before, but as the concentration is very small, it becomes an important marker of adulteration of cheese whey in milk. The techniques used for the detection of cheese whey in milk based on GMP are presented in Table 3 and explained as follows:

\subsection{Colorimetric methods}

In one approach, reaction of sialic acid with thiobarbituric acid, as suggested by Warren (1959), has been exploited for detection of cheese whey in milk. In a method proposed by Koning et al. (1966), precipitation of milk proteins has been done by TCA followed by GMP precipitation by phosphotungustic acid. In the GMP precipitates, sialic acid is estimated by TBA assay which is then correlated to the presence of GMP. This method was further used by Josephson et al. (1980) to detect cheese whey replacement for non-fat milk solids in ice milk mixes. Samples with GMP precipitate (per $100 \mathrm{~g}$ mix) having a dry weight above $55 \mathrm{mg}$ were said to be suspected.

Nakano and Ozimek (1999) reported that the estimation/detection of sialic acid in the reaction mixture after the removal of interfering $\mathrm{k}-\mathrm{CN}$ can provide indication of the presence of cheese whey in suspected milk or milk product samples. Fukuda et al. (1994) adapted a technique described earlier (Yao et al. 1989) wherein acidic ninhydrin was used as a chromophore for the determination of the concentration of sialic acid in sialoglycoprotein. In the same year, Fukuda (1994) proposed a spectrophotometric $(470 \mathrm{~nm})$ acidic ninhydrin method for quantitative determination of sialic acid, free or linked to the glycoprotein in fluid milk and rennet whey. This method required addition of TCA (final concentration 12\%) to remove the interfering proteins followed by precipitation of GMP using phosphotungstic acid. Alternatively, milk proteins can also be removed by $8 \%$ TCA followed by GMP precipitation with 14\% TCA (Rao et al. 2012). The precipitates on heating with acid ninhydrin reagent produced a yellow color, the absorbance of which was measured spectrophotometrically. Fukuda et al. (1996) proposed $A_{470} \leq 0.300(\leq 5.14 \mu \mathrm{g}$ free sialic acid per liter in milk samples) for the negative category, $A_{470}$ between 0.300 and 0.600 (5.14 and $10.64 \mu \mathrm{g}$ free sialic acid per liter of milk) for suspect, and $A_{470}>0.600(>10.64 \mu \mathrm{g}$ 


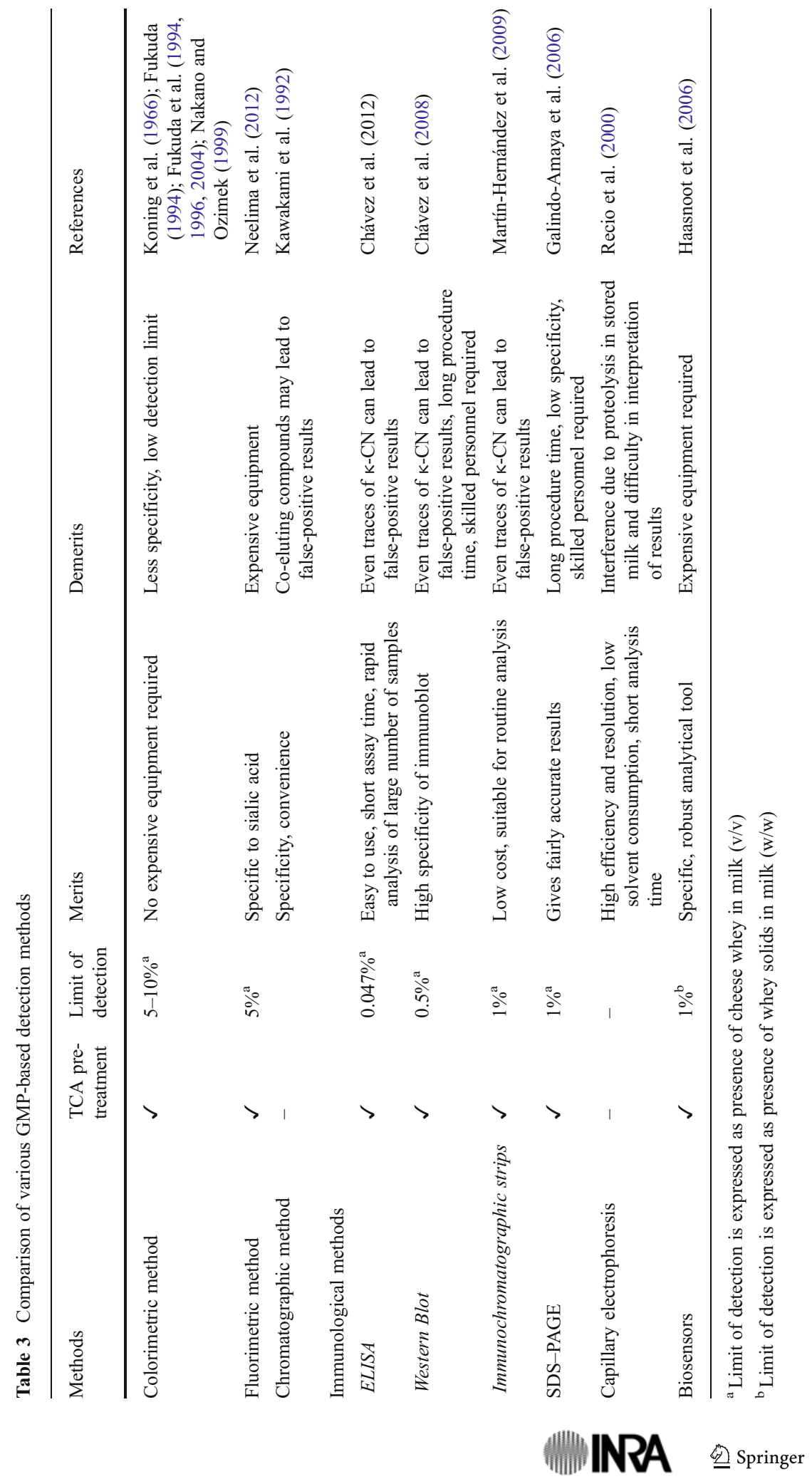


free sialic acid per liter in milk samples) for positive category of milk samples. Prata (2002) also confirmed that acidic ninhydrin reaction method can be efficiently used in fraud detection of whey addition to milk. In April 2003, the technique of acidic ninhydrin reaction for the quantitative determination of sialic acid was approved by the Brazilian Ministry of Agriculture as an Official method (Ministry of Agriculture Livestock and Food Supply of Brazil 2003). Later on, in their study, Fukuda et al. (2004) compared the acidic ninhydrin spectrophotometric method with European Union recommended HPLC method (Official Journal of the European Communities L 037, 2001) and found good correlation in these two methods.

Although sialic acid determination methods have been claimed to be sensitive, it is worth mentioning that the colorimetric methods for the determination of sialic acid (both TBA as well as ninhydrin based) are not specific and interfering substances may alter the results. This is evident by the presence of high blank values reported by Fukuda et al. (2004). Later, Matsuno and Suzuki (2008) have developed a new fluorimetric method for the estimation of sialic acid in glycoproteins. This method involves periodate oxidation of sialic acid (both bound as well as unbound) to formaldehyde followed by its estimation by Hantzsch reaction wherein a fluorescent compound is formed. The method is claimed to be specific for sialic acid and has been applied for detection of adulteration of milk with cheese whey (Neelima et al. 2012). In this method, selective precipitation of GMP was done using TCA wherein its concentration in milk was first raised to $5 \%$ to precipitate milk proteins, especially $\mathrm{K}-\mathrm{CN}$, followed by raising the TCA concentration to $14 \%$ to precipitate out GMP. In the precipitates, sialic acid was estimated using fluorimetric method and the fluorescence intensity was found to be linked to the level of sweet whey in adulterated milk samples. The method was found to detect the presence of 5\% sweet whey in milk. As these methods are based on the presence of sialic acid in GMP, loss of sialic from GMP during sample processing can significantly affect the results.

\subsection{SDS-PAGE}

A SDS-PAGE-based method has been developed for the detection of GMP in milk after the selective precipitation of GMP from milk using TCA. Galindo-Amaya et al. (2006) have isolated GMP from milk and adulterated milk sample with sequential precipitation in TCA ( $8 \%$ and $16 \%)$, treatment with ethanol-ether, and re-suspension in Tris- $\mathrm{HCl}$ buffer. Precipitates were analyzed by SDS-PAGE and GMP was evidenced as a trimer of $20.8 \mathrm{kDa}$ in samples of sweet whey, and mixtures of whey and milk $(1 \%, 5 \%, 10 \%$, and $50 \%)$, but absent in samples of acid whey and raw milk. The authors claim that the detection of GMP in milk using SDS-PAGE is a sensitive and specific method of detecting milk adulteration with whey, to levels as low as $1 \%$. The experience in authors' laboratory suggests that the trimer of GMP and $\mathrm{k}-\mathrm{CN}$ move closely and usually it is difficult to distinguish between them.

\subsection{Capillary electrophoresis}

$\mathrm{CE}$ has been proven to be a useful technique in the analysis of proteins, peptides, and their glycoforms (Chen et al. 1991; Kakehi and Honda 1996; Righetti 1996). In CE, small amounts of fluids are injected into a separation channel by using plug injection. 
Substances are separated based on their electrophoretic mobility, which is proportional to their charge to size in the interior of a small capillary filled with an electrolyte. Otte et al. (1995) have described a CE method for the separation of the major whey proteins using acidic and basic conditions. Under acidic conditions (70 mM phosphate, $\mathrm{pH}$ 2.5), a GMP peak was separated from the other whey proteins. Van Riel and Olieman (1995) employed the CE method for the detection of rennet whey solids in skim milk and buttermilk powder, based on the nonglycosylated A and B genetic variants of GMP. Later, Cherkaoui et al. (1997) validated a method for the analysis and quantitative determination of a GMP mixture. Commercially available GMP was used for method development and it was not applied to milk or whey samples. They used the $20-\mathrm{mM}$ sodium citrate buffer at $\mathrm{pH}$ 3.5. At this $\mathrm{pH}$, all GMP forms were anionic and the other whey proteins were cationic providing selectivity to the method. Recio et al. $(1996,2000)$ demonstrated the suitability of the CE method to identify GMP in liquid milk sample and observed the presence of detectable GMP in stored UHT milk samples incubated with psychrotrophs. The authors have observed that this might give rise to false-positive results when the presence of rennet whey is being investigated by CE. The CEbased method has not been used in the subsequent years as the result interpretation is difficult (due to fluctuation in migration) and the technique itself is technically demanding.

\subsection{Chromatographic methods}

HPLC using ion-exchange, gel permeation, hydrophobic interaction, and reversephase (RP) separations have become important techniques for separation and quantification of milk proteins as these combine versatility and short analysis time. Detection of GMP in cheese whey has been attempted by HPLC with a reasonable success. The work in this direction was initiated by Van Hooydonk and Olieman (1982) who described a gel permeation HPLC as a fast and sensitive method to monitor the action of chymosin in milk. Olieman and Bedem (1983) used this method to detect and estimate the presence of milk serum solids obtained by the action of the rennin in skimmed milk powder (SMP). The GMP detection by HPLC depends on the removal of the other proteins using TCA. To prevent interfering factors in the determination of GMP by chromatography, $8 \%$ TCA is considered as the best concentration at which the cheese whey proteins are virtually absent (Van Hooydonk and Olieman 1982). It has been reported that low concentrations of TCA result in removal of the whey proteins in low proportion, while high concentrations cause precipitation of larger amounts of GMP. Later on, Kawakami et al. (1992) described a method for determination of glycosylated and non-glycosylated GMP by sizeexclusion chromatography using two coupled TSK gel G3000 PW columns and anion-exchange chromatography on a Mono Q HR 5/5 column without pretreatment of samples with TCA. The superiority of the method described was to distinguish heterogeneous GMP by the variations in carbohydrate moiety and to determine GMP content without pre-treatment of milk samples with TCA. The concepts developed for all these methods were later on used for the development of European Union (EU) methods for the detection of frauds of addition of whey for the manufacture of dried milks. 
Adulteration of SMP is particularly attractive as the EU subsidizes the public storage of SMP and the processing of these powders intended for animal feed. To be eligible for EU subsidy, milk powders must be prepared exclusively from skim milk and should not contain solids from whey. To combat subsidy fraud, the EU has imposed two-step methods (screening followed by confirmatory) for the detection of rennet whey in dried milks (Official Journal of the European Communities L 037, 2001). The initial screening method involved gel permeation chromatography for all samples, followed by a confirmation step using RP-HPLC. Both methods detect the presence of GMP in the sample. The screening method requires reconstitution of the SMP, removal of fat and proteins with TCA, followed by centrifugation. GMP is then determined in the supernatant by gel filtration HPLC using UV detection at $205 \mathrm{~nm}$. The results are then required to be evaluated vis-à-vis results obtained for the samples by reference to standard samples consisting of SMP with or without the addition of a known percentage of whey powder. If the sample indicates the presence of GMP by the preliminary method, the results are further confirmed by a RP-HPLC procedure using UV-vis detection at $210 \mathrm{~nm}$. The method could detect presence of $1 \%$ rennet whey solids in SMP. Ferreira and Oliveira (2003) have employed the RP-HPLC using polystyrenedivinylbenzene column which has excellent chemical and $\mathrm{pH}$ stability and is quite robust. The workers have employed $\mathrm{pH} 4.6$ filtrate from the adulterated samples, and the sample was eluted using the gradient of two solvents. Solvent A was $0.1 \%$ trifluoroacetic acid (TFA) in water and solvent B was 95\% acetonitrile-5\% water- $0.1 \%$ TFA. The eluate was monitored by a UV detector at $214 \mathrm{~nm}$ and enabled the separation of three peaks, two of which corresponded to the aGMP components of the two principal genetic variants (A and B), and were eluted after the less wellresolved gGMP components. GMP in samples was calculated from integrating and peak identification was carried out by comparison with commercially purified bovine whey protein standards.

\subsection{Immunological methods}

In these types of methods, antibodies are raised against GMP or $\mathrm{k}-\mathrm{CN}$ which is then used to develop various techniques to visualize antigen-antibody reaction. Although immunological methods are credited for their specificity, they give false-positive results if even a trace amount of $\mathrm{k}-\mathrm{CN}$ (from which GMP derives) is present in the sample. Some of these techniques are described below:

\subsubsection{Enzyme-linked immunosorbent assay (ELISA)}

An inhibition ELISA for the detection of bovine rennet whey solids in SMP and buttermilk powder has been developed (Bremer et al. 2008). The affinity purified monoclonal antibodies developed against bovine $\mathrm{k}-\mathrm{CN}$ which could recognize bovine GMP were used in this ELISA. The removal of $\mathrm{K}-\mathrm{CN}$ was achieved by precipitation of all milk proteins using TCA. The rennet whey content was determined in a neutralized TCA sample extract by binding of the soluble GMP to a peroxidaselabeled anti-bovine-k-CN monoclonal antibody. For quantitative assay, calibration curves were constructed by analyzing SMP standards with different known concentrations of rennet whey $(0-5.8 \%, w / w)$. The assay has a limit of detection of $0.1 \%(w /$ 
w) rennet whey powder in SMP with high repeatability and reliability. Recently, a sandwich ELISA for the detection and quantification of whey in raw milk and milk products has been developed using a polyclonal rabbit anti-GMP antibody (Chávez et al. 2012). In the assay, 96-well microplates are coated overnight with rabbit anti-GMP antibodies. GMP in the TCA-treated sample is then conjugated to it followed by binding with biotinylated rabbit anti-GMP antibody. The complex is then made to react with $\mathrm{HRP}$-avidin followed by addition of substrate. The method can detect presence of $0.047 \%$ of cheese whey in milk with quantification limit of $0.14 \%(\mathrm{v} / \mathrm{v})$.

\subsubsection{Western blot}

Western blotting (protein blotting or immunoblotting) is a powerful and important procedure for the immunodetection of proteins post-electrophoresis, particularly proteins that are of low abundance. Chávez et al. (2008) have developed a Western blot protocol for the detection of GMP in adulterated milk samples. The method was developed using affinity purified specific polyclonal anti-GMP antibodies. When used in Western blot, these anti-GMP antibodies recognized two bands of 20.1 and $14 \mathrm{kDa}$ for pure GMP. In cheese whey, one more band of molecular weight of $45 \mathrm{kDa}$ was visualized. This phenomenon of recognition of different bands has been ascribed to the self-aggregation of GMP leading to the formation of dimers, trimers, tetramers, etc. (Galindo-Amaya et al. 2006). The authors have reported more abundance of GMP aggregates of $20.1 \mathrm{kDa}$ than 14 or $45 \mathrm{kDa}$ in pure GMP as well as in whey, indicating the higher amount of trimer form. They have finally recommended the presence of a GMP-specific band at $20.1 \mathrm{kDa}$ as marker of adulteration. Sample preparation involves mixing of liquid samples with TCA to a final concentration of $8 \%$ in order to precipitate $\mathrm{k}-\mathrm{CN}$ which cross-react with GMP. The GMP was precipitated with 14\% TCA and used for immunoblot after dissolving in buffer. This method can detect $0.5 \%(\mathrm{v} / \mathrm{v})$ of liquid whey in milk in $4.5 \mathrm{~h}$. The use of polyclonal antibodies instead of monoclonal antibodies is justified since different food processing techniques can affect their proteins or peptides, for example, by destroying specific epitopes.

\subsubsection{Immunochromatographic strips}

The lateral flow assay (LFA), also called the immunochromatographic assay or the strip assay, is a simple device intended to detect the presence (or absence) of a target analyte in the sample (matrix). This technique is based on an immunochromatographic procedure that utilizes antigen-antibody properties and enables rapid detection of the analyte. A LFA-based dipstick test has been developed for the fast detection of bovine rennet whey in liquid milk and milk powder (Martín-Hernández et al. 2009). The test is based on the binding of GMP by two different anti-bovine $\mathrm{k}-\mathrm{CN}$ monoclonal antibodies and has a visual detection limit of around $15 \mathrm{ng} \mathrm{mL}^{-1}$ for GMP and $1 \%(\mathrm{v} / \mathrm{v})$ for rennet whey in milk using standards and spiked samples. The dipstick performance was evaluated in a collaborative trial using SMP and raw, pasteurized, and UHT milk. These researchers also demonstrated the suitability of the dipstick in comparison with gel permeation-high performance liquid chromatography and a colorimetric method by analyzing 60 raw milk samples collected from farms in Brazil. The dipstick results correlated well with the 
HPLC results and were more reliable than those obtained with the colorimetric method. The dipstick test correctly identified all raw milk samples with rennet whey content above $4 \%$. Since monoclonal antibodies were raised against $\mathrm{k}-\mathrm{CN}$, the prior removal of $\mathrm{k}-\mathrm{CN}$ from the milk sample is necessary and this has been done by adding $20 \%$ TCA to a final concentration of $8 \%$. The technique has been commercialized by Operon under the brand name Immunostick c-GMP. The method has been evaluated by Oancea (2009) and has found its applicability in unprocessed and processed milk, condensed milk, powdered milk, and dairy beverages of cappuccino, chocolate, banana, and strawberry flavors. For quantitative analysis, an immunochromatic reader was used.

\subsection{Biosensors for detection of GMP}

Haasnoot et al. (2006) have developed a surface plasmon resonance (SPR)-based biosensor for the detection of fraudulent addition of whey in milk and milk powder. The SPR method is based on optical measurement of refractive index changes associated with the binding of analyte molecules in a sample to biorecognize molecules immobilized on the SPR sensor. In their study, the authors have immobilized monoclonal antibodies raised against $\mathrm{K}$-casein onto the chip surface and the binding of GMP was measured using SPR. The authors have used Biacore biosensors (Biacore AB, Uppsala, Sweden) which have been proven to be robust analytical tools for the automated immunochemical detection of whey in milk and milk powder. However, the significant cost of the instruments is a disincentive for their wide application in food control laboratories. The authors have also proposed an alternative low-cost optical biosensor (Spreeta; Texas Instruments, Attleboro, MA, USA). Using this prototype biosensor, an inhibition immunoassay for bovine $\mathrm{k}-\mathrm{CN}$ was evaluated for the detection of bovine rennet whey powder in milk powder. Comparable sensitivities were obtained for Spreeta-based biosensor and a Biacore 3000 instrument. The method has been claimed to detect the presence of $1 \%$ bovine rennet whey powder in milk powder.

Although a number of approaches have been attempted to develop methods for the detection of cheese whey in milk using GMP as a marker, these methods have not been validated and are not in use with a few exceptions (ninhydrin and HPLC-based methods). Also, in the authors' laboratory different attempts have been made to develop a protocol for the detection of cheese whey in milk involving electrophoresis, Western blot using antibody and carbohydrate-based detection, and LFA (unpublished data). It has been experienced that the chances of getting false-positive results are greater with all these sensitive methods. It appears that native GMP in pure milk samples, as indicated earlier also by Furlanetti and Prata (2003), may be the cause of high false-positive data. This warrants more research to establish the presence of native GMP in pure milk which may appear in milk due to incomplete synthesis of $\mathrm{K}$ $\mathrm{CN}$ in mammary gland or due to microbial action post-milking.

\section{Conclusions}

GMP is a bioactive peptide with unique chemical properties (glycosylation, absence of aromatic amino acids, self-association, etc.) present in cheese or rennet whey. 
Apart from the many biological properties, the peptide has a number of functional properties (emulsification and foaming properties, gel formation) making it an ingredient of choice. Some of the dairy ingredient companies have already realized the potential and is being promoted as a premium ingredient isolated from whey. Potential applications of GMP include its addition in the diet of hepatic and phenylketonuria patients. The addition of GMP to infant formula has been questioned due to its high threonine content (12 to 13 threonine residues) which resulted in higher plasma threonine concentrations (hyperthreoninemia) in GMP containing formula-fed infants vis-à-vis breastfed infants (Rigo et al. 2001). However, later work (Sandström et al. 2008) has not found any such disparity and suggested that the difference in plasma threonine concentrations between formula-fed and breastfed infants could be due to a difference in threonine metabolism. This fact needs to be studied further to arrive at a definite conclusion. The application of GMP as a functional ingredient coupled with its wide $\mathrm{pH}$ range solubility and heat stability in specialized products needs to be further explored. However, the high cost of GMP may be a hindrance in its use as a functional ingredient. The research challenge is in its selective isolation from cheese whey on a commercial scale, while keeping the other whey component or protein intact for other uses. Although there are numerous protocols for GMP isolation, there is a tremendous scope to develop simplified and reproducible methods for its large-scale production. The exact reason behind the selfassociation of GMP at different $\mathrm{pH}$ is still required to be investigated thoroughly. GMP as a marker of adulteration of milk with cheese whey has been exploited to a great extent, and almost all of the detection protocols except some chromatographic methods have employed TCA for the removal of interfering $\mathrm{k}-\mathrm{CN}$ from milk samples. Among the sensitive immunological techniques, ELISA and Western blot are technically demanding but LFA is convenient. Although the LFA method appears to be promising and it has been commercialized, it inherits the problem of false-positive results like other sensitive methods. The efficacy of these methods also needs to be validated in stored and fermented milk wherein proteolysis may give rise to GMP-like peptides.

Open Access This article is distributed under the terms of the Creative Commons Attribution License which permits any use, distribution, and reproduction in any medium, provided the original author(s) and the source are credited.

\section{References}

Aimutis WR (2004) Bioactive properties of milk proteins with particular focus on anticariogenesis. J Nutr 134:989-995

Aleinik SI, Stan EY, Chernikov MP (1984) A glycopeptide from K-casein and its effect on protein assimilation. Voprosy Pitaniya 2:47-50

Azuma N, Yamauchi K, Mitsuoka T (1984) Bifidus growth-promoting activity of a glycomacropeptide derived from human K-casein. Agric Biol Chem 48:2159-2162

Beucher S, Levenez F, Yvon M, Corring T (1994) Effects of gastric digestive products from casein on CCK release by intestinal cells in rat. J Nutr Biochem 5:578-584

Bönisch MP, Huss M, Weitl K, Kulozik U (2007) Transglutaminase cross-linking of milk proteins and impact on yoghurt gel properties. Int Dairy J 17:1360-1371

Bremer MGEG, Kemmers-Voncken AEM, Boers EAM, Frankhuizen R, Haasnoot W (2008) Enzymelinked immunosorbent assay for the detection of bovine rennet whey powder in milk powder and buttermilk powder. Int Dairy J 18:294-302

Brody EP (2000) Biological activities of bovine glycomacropeptide. Br J Nutr 84:39-46

Burton J, Skudder PJ (1987) Whey proteins. UK patent Application GB 2188526 A1 
Burton-Freeman BM (2008) Glycomacropeptide (GMP) is not critical to whey-induced satiety, but may have a unique role in energy intake regulation through cholecystokinin (CCK). Physiol Behav 93:379387

Chávez NA, Jauregui J, Palomares LA, Macías KE, Jiménez M, Salinas E (2012) A highly sensitive sandwich ELISA for the determination of glycomacropeptide to detect liquid whey in raw milk. Dairy Sci Technol 92:121-132

Chávez NA, Salinas E, Jauregui J, Palomares LA, Macias K (2008) Detection of bovine milk adulterated with cheese whey by western blot immunoassay. Food Agric Immunol 19:265-272

Chen FT, Liu CM, Hsieh YZ, Sternberg JC (1991) Capillary electrophoresis-a new clinical tool. Clin Chem 37(1):14-19

Cherkaoui S, Doumenc N, Tachon P, Neeser JR, Veuthey JL (1997) Development of a capillary zone electrophoresis method for caseinoglycomacropeptide determination. J Chromatogr A 790:195-205

Chobert J, Touati A, Bertrand Harb C, Dalgalarrondo M, Nicolas MG (1989) Solubility and emulsifying properties of kappa casein and its caseinomacropeptide. J Food Biochem 13:457-473

Czernicka M, Domagala J, Sady M, Wieteska I (2009) Functional properties of milk proteins modified by transglutaminase depending on incubation conditions with the enzyme. Biotechnol Anim Husb 25:737-743

da Silva C, Coimbra JSR, Rojas EEG, Teixeira J (2009) Partitioning of glycomacropeptide in aqueous twophase systems. Process Biochem 44:1213-1216

De Souza E, Arruda S, Brandao P, Siqueira E (2000) Electrophoretic analysis to detect and quantify additional whey in milk and dairy beverages. Ciênc Tecnol Aliment 20:1-8

Delfour A, Jolles J, Alais C (1965) Caseino-glycopeptides: characterization of a methionin residue and of the N-terminal sequence. Biochem Biophys Res Commun 19:452-455

Dickinson E (2003) Interfacial, emulsifying and foaming proprieties of milk proteins. In: Fox PF, McSweeney PLH (eds) Advanced dairy chemistry vol. 1: proteins, part B, 3rd edn. Kluwer/Plenum, New York, pp 1229-1260

Eigel W, Butler J, Ernstrom C, Farrell H, Harwalkar V, Jenness R, Whitney RML (1984) Nomenclature of proteins of cow's milk: fifth revision. J Dairy Sci 67:1599-1631

El-Salam M, El-Shibiny S, Buchheim W (1996) Characteristics and potential uses of the casein macropeptide. Int Dairy J 6:327-341

Farías M, Martinez M, Pilosof A (2010) Casein glycomacropeptide pH-dependent self-assembly and cold gelation. Int Dairy J 20:79-88

Fernando SF, Woonton BW (2010) Quantitation of N-acetylneuraminic (sialic) acid in bovine glycomacropeptide (GMP). J Food Compos Anal 23:359-366

Ferreira IM, Oliveira M (2003) Determination of caseinomacropeptide by an RP-HPLC method and monitoring of the addition of rennet whey to powdered milk. J Liq Chromatogr Relat Technol 26:99-107

Fox PF, McSweeney PLH (1998) Dairy chemistry and biochemistry. Kluwer/Plenum, New York

Fukuda P, Röig M, Prata LF (1994) Metodologia quantitativa para determinação espectrofotométrica de ácido siálico em leite [Quantitative methodology for the spectrophotometric determination of sialic acid in milk]. In: Anais do XII Congresso Nacional de Laticínios, Juiz de Fora, MG, Brasil [In: Proceedings of the XII National Congress of Dairy Products, Juiz de Fora, MG, Brazil]

Fukuda S, Roig S, Prata LF (1996) Aplicação do método da ninidrina ácida como teste de "screening" de plataforma para a detecção da adição de soro ao leite [Application of the ninhydrin test as acid "screening" platform for the detection of the addition to milk serum]. Ciênc Tecnol Aliment 16:52-56

Fukuda SP (1994) Estudo de metodologia quantitative para determinação espectrofotométrica de ácido siálico em leite [Methodology for the study of quantitative spectrophotometric determination of sialic acid in milk]. Dissertação-Faculdade de Engenharia de Alimentos, Universidade Estadual de Campinas, SP, Brazil

Fukuda SP, Roig SM, Prata LF (2004) Correlation between acidic ninhydrin and HPLC methods to evaluate fraudulent addition of whey in milk. Dairy Sci Technol 84:501-512

Furlanetti AM, Prata LF (2003) Free and total GMP (glycomacropeptide) contents of milk during bovine lactation. Ciênc Tecnol Aliment 23:121-125

Galindo-Amaya LL, Valbuena-Colmenares E, Rojas-Villarroel E (2006) Standardization of glycomacropeptide detection with SDS-PAGE as a milk adulteration index. Rev Cient (Maracaibo) 16:308-314

György P, Norris RF, Rose CS (1954) Bifidus factor. I. A variant of Lactobacillus bifidus requiring a special growth factor. Arch Biochem Biophys 48:193-201

Haasnoot W, Marchesini GR, Koopal K (2006) Spreeta-based biosensor immunoassays to detect fraudulent adulteration in milk and milk powder. J AOAC Int 89:849-855

Josephson R, Holloway-Thomas DJ, Warthesen J (1980) Cheese whey detection in frozen desserts. J Dairy Sci 63:1356-1360 
Kakehi K, Honda S (1996) Analysis of glycoproteins, glycopeptides and glycoprotein-derived oligosaccharides by high-performance capillary electrophoresis. J Chromatogr A 720:377-393

Kawakami H, Kawasaki Y, Dosako S, Tanimoto M, Nakajima I (1992) Determination of kappa-casein glycomacropeptide by high performance liquid chromatography without trichloroacetic acid pretreatment. Milchwissenschaft 47:688-693

Kawasaki Y, Isoda H, Tanimoto M, Dosako S, Idota T, Ahiko K (1992) Inhibition by lactoferrin and kappacasein glycomacropeptide of binding of Cholera toxin to its receptor. Biosci Biotechnol Biochem 56:195

Kawasaki Y, Isoda K, Shinmoto H, Tanimoto M, Dosako S, Idota T, Nakajima I (1993a) Inhibition by kcasein glycomacropeptide and lactoferrin of influenza virus hemagglutination. Biosci Biotechnol Biochem 57:1214-1215

Kawasaki Y, Kawakami H, Tanimoto M, Dosako S, Tomizawa A, Kotake M, Nakajima I (1993b) pHdependent molecular-weight changes of kappa-casein glycomacropeptide and its preparation by ultrafiltration. Milchwissenschaft 48:191-196

Koning P, Elisses J, De Vries H (1966) A method for the detection of small percentages of whey powder in milk powder. Neth Milk Dairy J 20:203-212

Kreuß M, Krause I, Kulozik U (2008) Separation of a glycosylated and non-glycosylated fraction of caseinomacropeptide using different anion-exchange stationary phases. J Chromatogr A 1208:126-132

Kreuß M, Krause I, Kulozik U (2009a) Influence of glycosylation on foaming properties of bovine caseinomacropeptide. Int Dairy J 19:715-720

Kreuß M, Kulozik U (2009) Separation of glycosylated caseinomacropeptide at pilot scale using membrane adsorption in direct-capture mode. J Chromatogr A 1216:8771-8777

Kreuß M, Strixner T, Kulozik U (2009b) The effect of glycosylation on the interfacial properties of bovine caseinomacropeptide. Food Hydrocoll 23:1818-1826

LaClair CE, Ney DM, MacLeod EL, Etzel MR (2009) Purification and use of glycomacropeptide for nutritional management of phenylketonuria. J Food Sci 74:199-206

Li EWY, Mine Y (2004) Comparison of chromatographic profile of glycomacropeptide from cheese whey isolated using different methods. J Dairy Sci 87:174-177

Lieske B, Konrad G (1996) A new method to estimate caseinomacropeptide and glycomacropeptide from trichloroacetic acid filtrates. Milchwissenschaft 51:431-434

Lieske B, Konrad G, Kleinschmidt T (2004) Isolation of caseinomacropeptide from rennet whey by a multistage ultrafiltration process. II. Influence of $\mathrm{pH}$ and heating on the carbohydrate moiety of glycomacropeptide. Milchwissenschaft 59:291-294

Marshall SC (1991) Casein macropeptide from whey. A new product opportunity. Food Res Quart 51:86-91

Martin-Diana AB, Frias J, Fontecha J (2005) Emulsifying properties of whey protein concentrate and caseinomacropeptide of cow, ewe and goat. Milchwissenschaft 60:363-366

Martin-Diana AB, Pelaez C, Requena T (2004) Rheological and structural properties of fermented goat's milk supplemented with caseinomacropeptide and whey protein concentrate. Milchwissenschaft 59:383-386

Martín-Hernández C, Muñoz M, Daury C, Weymuth H, Kemmers-Voncken AEM, Corbatón V, Toribio T, Bremer MGEG (2009) Immunochromatographic lateral-flow test strip for the rapid detection of added bovine rennet whey in milk and milk powder. Int Dairy J 19:205-208

Martin-Diana A, Gomez-Guillén M, Montero P, Fontecha J (2006) Viscoelastic properties of caseinmacropeptide isolated from cow, ewe and goat cheese whey. J Sci Food Agric 86:1340-1349

Martinez MJ, Carrera Sánchez C, Rodríguez Patino JM, Pilosof AMR (2009) Bulk and interfacial behaviour of caseinoglycomacropeptide (GMP). Colloid Surf B Biointerface 71:230-237

Martinez MJ, Carrera Sánchez C, Rodríguez Patino JM, Pilosof AMR (2012) Interactions between $\beta$ lactoglobulin and casein glycomacropeptide on foaming. Colloid Surf B Biointerface 89:234-241

Matsuno K, Suzuki S (2008) Simple fluorimetric method for quantification of sialic acids in glycoproteins. Anal Biochem 375:53-59

Mikkelsen TL, Frøkiær H, Topp C, Bonomi F, Iametti S, Picariello G, Ferranti P, Barkholt V (2005) Caseinomacropeptide self-association is dependent on whether the peptide is free or restricted in kappa-casein. J Dairy Sci 88:4228-4238

Ministry of Agriculture, Livestock and Food Supply of Brazil (2003) Instruction of the Secretariat of Agricultural Protection No. 22, 14 April 2003 formalises physico-chemical analytical methods to control milk and milk products, Official Gazette, 02 May, 3-25

Miralles B, Bartolomé B, Amigo L, Ramos M (2000) Comparison of three methods to determine the whey protein to total protein ratio in milk. J Dairy Sci 83:2759-2765

Mollé D, Léonil J (2005) Quantitative determination of bovine k-casein macropeptide in dairy products by liquid chromatography/electrospray coupled to mass spectrometry (LC-ESI/MS) and 
liquid chromatography/electrospray coupled to tandem mass spectrometry (LC-ESI/MS/MS). Int Dairy J 15:419-428

Mollé D, Léonil J (1995) Heterogeneity of the bovine K-casein caseinomacropeptide, resolved by liquid chromatography on-line with electrospray ionization mass spectrometry. J Chromatogr A 708:223-230

Moreno FJ, López-Fandiño R, Olano A (2002) Characterization and functional properties of lactosyl caseinomacropeptide conjugates. J Agric Food Chem 50:5179-5184

Morr C, Seo A (1988) Fractionation and characterization of glycomacropeptide from caseinate and skim milk hydrolysates. J Food Sci 53:80-87

Mrowetz G, Klostermeyer H (1976) Polarographic determination of the whey protein percentage in dried milks. Milchwissenschaft 31:346-349

Nakajima K, Tamura N, Kobayashi-Hattori K, Yoshida T, Hara-Kudo Y, Ikedo M, Sugita-Konishi Y, Hattori M (2005) Prevention of intestinal infection by glycomacropeptide. Biosci Biotechnol Biochem 69:2294-2301

Nakano T, Ozimek L (1998) Gel chromatography of glycomacropeptide (GMP) from sweet whey on sephacryls-200 at different pH's and on Sephadex G-75 in 6M guanidine hydrochloride. Milchwissenschaft 53:629-633

Nakano T, Ozimek L (1999) Determination of sialic acid by the thiobarbituric acid reaction in sweet whey and its fractions. J Agric Food Chem 47:2613-2616

Nakano T, Ozimek L (2000a) Purification of glycomacropeptide from caseinate hydrolysate by gel chromatography and treatment with acidic solution. J Food Sci 65:588-590

Nakano T, Ozimek L (2000b) Purification of glycomacropeptide from dialyzed and non-dialyzed sweet whey by anion-exchange chromatography at different $\mathrm{pH}$ values. Biotechnol Lett 22:1081-1086

Nakano T, Ozimek L (2002) Isolation of glycomacropeptide from sweet whey by gel chromatography on Sephacryl S-200 at pH 7.0 and 3.5. Milchwissenschaft 57:128-130

Neelima, Sharma R, Rajput YS (2012) Direct estimation of sialic acid in milk and milk products by fluorimetry and its application in detection of sweet whey adulteration in milk. J Dairy Res 79:495-501

Neeser J, Chambaz A, Del Vedovo S, Prigent M, Guggenheim B (1988) Specific and nonspecific inhibition of adhesion of oral actinomyces and streptococci to erythrocytes and polystyrene by caseinoglycopeptide derivatives. Infect Immun 56:3201-3208

Neeser JR, Golliard M, Woltz A, Rouvet M, Dillmann ML, Guggenheim B (1994) In vitro modulation of oral bacterial adhesion to saliva-coated hydroxyapatite beads by milk casein derivatives. Oral Microbiol Immunol 9:193-201

Oancea S (2009) Identification of glycomacropeptide as indicator of milk and dairy drinks adulteration with whey by immunochromatographic assay. Roman Biotechnol Lett 14:4146-4151

Official Journal of the European Communities L 037 (2001) Regulation No. 213/2001, 07/02/2001, 1-99

Olieman C, Bedem J (1983) A sensitive HPLC method of detecting and estimating rennet whey total solids in skim milk powder. Neth Milk Dairy J 37:27-36

Oliva Y, Escobar A, Ponce P (2002) Caseinomacropéptido bovino: una alternativa para la salud. Rev Salud Anim 24:73-81

Oliveira L, Sarubbo L, Porto A, Campos-Takaki G, Tambourgi E (2002) Partition of trypsin in aqueous two-phase systems of poly (ethylene glycol) and cashew-nut tree gum. Process Biochem 38:693-699

Otani H, Monnai M (1993) Inhibition of proliferative responses of mouse spleen lymphocytes by bovine milk K-casein digests. Food Agric Immunol 5:219-229

Otani H, Monnai M, Hosono A (1992) Bovine k-casein as inhibitor of the proliferation of mouse splenocytes induced by lipopolysaccharide stimulation. Milchwissenschaft 47:512-515

Otte J, Midtgaard L, Qvist KB (1995) Analysis of caseinomacropeptide(s) by free solution capillary electrophoresis. Milchwissenschaft 50:75-79

Prata LF (2002) Distribuição de GMP livre, em leites crus e pasteurizados, na definição da detecção de fraudes por adição de soro [Distribution of free GMP in raw and pasteurized milk, in the definition of fraud detection by addition of serum]. Thesis, Faculdade de Ciências Agrárias e Veterinárias, UNESP, Jaboticabal, SP, Brazil

Rao PS, Kundu M, Sharma N, Sharma R, Rajput YS (2012) A spectrophotometric method for the detection of cheese whey in milk. Indian J Dairy Sci 65:300-304

Recio I, García-Risco MR, López-Fandiño R, Olano A, Ramos M (2000) Detection of rennet whey solids in UHT milk by capillary electrophoresis. Int Dairy J 10:333-338

Recio I, López-Fandiño R, Olano A, Olieman C, Ramos M (1996) Study of the formation of caseinomacropeptides in stored ultra-high-temperature-treated milk by capillary electrophoresis. J Agric Food Chem 44:3845-3848 
Requena P, Gonzalez R, Lopez-Posadas R, Abadia-Molina A, Suarez MD, Zarzuelo A, Medina FS, Martinez-Augustin O (2010) The intestinal antiinflammatory agent glycomacropeptide has immunomodulatory actions on rat splenocytes. Biochem Pharmacol 79:1797-1804

Righetti PG (1996) Capillary electrophoresis in analytical biotechnology. CRC, Boca Raton

Rigo J, Boehm G, Georgi G, Jelinek J, Nyambugabo K, Sawatzki G, Studzinski F (2001) An infant formula free of glycomacropeptide prevents hyperthreoninemia in formula-fed preterm infants. J Pediatr Gastroenterol Nutr 32:127-130

Robitaille G, Lapointe C, Leclerc D, Britten M (2012) Effect of pepsin-treated bovine and goat caseinomacropeptide on Escherichia coli and Lactobacillus rhamnosus in acidic conditions. J Dairy Sci 95:1-8

Saito T, Yamaji A, Itoh T (1991) A new isolation method of caseinoglycopeptide from sweet cheese whey. J Dairy Sci 74:2831-2837

Salcedo J, Lacomba R, Alegría A, Barbera R, Matencio E, Lagarda MJ (2011) Comparison of spectrophotometric and HPLC methods for determining sialic acid in infant formulas. Food Chem 127:19051910

Sandström O, Lönnerdal B, Graverholt G, Hernell O (2008) Effects of $\alpha$-lactalbumin enriched formula containing different concentrations of glycomacropeptide on infant nutrition. Am J Clin Nutr 87:921-928

Silva-Hernandez ER, Nakano T, Ozimek L (2002) Isolation and analysis of K-casein glycomacropeptide from goat sweet whey. J Agric Food Chem 50:2034-2038

Tanimoto M, Kawasaki Y, Dosako S, Ahiko K, Nakajima I (1992) Large-scale preparation of K-casein glycomacropeptide from rennet casein whey. Biosci Biotechnol Biochem 56:140-141

Taylor CM, Woonton BW (2009) Quantity and carbohydrate content of glycomacropeptide fractions isolated from raw and heat-treated milk. Int Dairy J 19:709-714

Thomä-Worringer C, Siegert N, Kulozik U (2007) Foaming properties of caseinomacropeptide_-1. Impact of concentration and interactions with whey protein. Milchwissenschaft 62:249-252

Thomä-Worringer C, Sørensen J, López-Fandiño R (2006) Health effects and technological features of caseinomacropeptide. Int Dairy J 16:1324-1333

Thomä C, Krause I, Kulozik U (2006) Precipitation behaviour of caseinomacropeptides and their simultaneous determination with whey proteins by RP-HPLC. Int Dairy J 16:285-293

Tolkach A, Kulozik U (2005) Fractionation of whey proteins and caseinomacropeptide by means of enzymatic crosslinking and membrane separation techniques. J Food Eng 67:13-20

Tullio LT, Lazzari Karkle EN, Cândido LMB (2007) Revisão: isolamento e purificação do glicomacropeptídeo do soro de leite [Review: isolation and purification of glycomacropeptide the serum of milk]. Boletim do Centro de Pesquisa de Processamento de Alimentos 25:121-132

van Calcar SC, Ney DM (2012) Food products made with glycomacropeptide, a low-phenylalanine whey protein, provide a new alternative to amino acid-based medical foods for nutrition management of phenylketonuria. J Acad Nutr Diet 112:1201-1210

Van Hooydonk A, Olieman C (1982) A rapid and sensitive high-performance liquid chromatography method of following the action of chymosin in milk. Neth Milk Dairy J 36:152-158

Van Riel J, Olieman C (1995) Determination of caseinomacropeptide with capillary zone electrophoresis and its application to the detection and estimation of rennet whey solids in milk and buttermilk powder. Electrophor 16:529-533

Vasilevskaya L, Stan EY, Chernikov M, Shlygin G (1977) Inhibitory action of glycomacropeptide produced on the gastric secretion by various humoral stimulants. Voprosy Pitaniya 4:21-24

Warren L (1959) The thiobarbituric acid assay of sialic acids. J Biol Chem 234:197-1975

Wolfschoon-Pombo AF, Furtado MAM (1989) Detection of adulteration of pasteurised milk with whey by determination of the casein-bound phosphorus and protein nitrogen content. Eur Food Res Technol 188:16-21

Wong PYY, Nakamura S, Kitts DD (2006) Functional and biological activities of casein glycomacropeptide as influenced by lipophilization with medium and long chain fatty acid. Food Chem 97:310-317

Wu J, Wang Y, Huang L (2012) Separation of glycomacropeptide (a functional protein material) by aqueous two-phase systems. Adv Mater Res 496:185-188

Yao K, Ubuka T, Masuoka N, Kinuta M, Ikeda T (1989) Direct determination of bound sialic acids in sialoglycoproteins by acidic ninhydrin reaction. Anal Biochem 179:332-335 